Leishmanicidal, antiplasmodial and cytotoxic activity of indole alkaloids from Corynanthe pachyceras

Staerk, D; Lemmich, E; Christensen, J; Kharazmi, A; Olsen, C E; Jaroszewski, J W

Published in:

Planta Medica

Publication date:

2000

Document version

Publisher's PDF, also known as Version of record

Citation for published version (APA):

Staerk, D., Lemmich, E., Christensen, J., Kharazmi, A., Olsen, C. E., \& Jaroszewski, J. W. (2000).

Leishmanicidal, antiplasmodial and cytotoxic activity of indole alkaloids from Corynanthe pachyceras. Planta Medica, 66, 531-536. 


\title{
Leishmanicidal, Antiplasmodial and Cytotoxic Activity of Indole Alkaloids from Corynanthe pachyceras
}

\author{
Dan Stærk', Else Lemmich¹, Jette Christensen¹, Arsalan Kharazmi², Carl Erik Olsen³, Jerzy W. Jaroszewski ${ }^{1, *}$ \\ ${ }^{1}$ Department of Medicinal Chemistry, The Royal Danish School of Pharmacy, Copenhagen, Denmark \\ ${ }^{2}$ Centre for Medical Parasitology, Department of Clinical Microbiology, University Hospital, Copenhagen, Denmark \\ ${ }^{3}$ Department of Chemistry, The Royal Veterinary and Agricultural University, Frederiksberg, Denmark
}

Received: September 30, 1999; Accepted: February 6, 2000

\begin{abstract}
Five indole alkaloids, corynantheidine, corynantheine, dihydrocorynantheine, $\alpha$-yohimbine and corynanthine were isolated from bark of Corynanthe pachyceras K. Schum. (Rubiaceae). The structures were established by spectroscopic methods, inlcuding previously unreported assignment of all ${ }^{1} \mathrm{H}$ NMR resonances by COSY and NOESY experiments. These and related alkaloids showed pronounced activity against Leishmania major promastigotes ( $\mathrm{IC}_{50}$ at the micromolar level) but no significant in vitro antiplasmodial activity (against chloroquinesensitive Plasmodium falciparum). Cytotoxicity assessed with drug sensitive KB-3-1 and multidrug-resistant KB-V1 cell lines was low; the alkaloids are apparently not substrates for the Pglycoprotein (P-170) efflux pump.
\end{abstract}

Key words: Indole alkaloids, Plasmodium, Leishmania, multidrug resistance, NMR.

\section{Introduction}

Corynanthe pachyceras K. Schum. [syn. Pausinystalia pachyceras (K. Schum.) De Wild., Pseudocinchona pachyceras (K. Schum.) A. Chev., Pseudocinchona africana A. Chev.] is a lower storey forest tree growing in tropical West Africa. In Ghana, the plant is used as intoxicant, local anaesthetic, and a febrifuge (1). This and related Rubiaceae species, such as C.johimbe K. Schum., are the classical sources of indole alkaloids of the yohimbine- and corynantheine-type. In a screening program for antimalarial and leishmanicidal plants conducted at this laboratory, crude extracts of bark of C. pachyceras exhibited a high activity. Isolation and characterization of active constituents responsible for this activity is described below.

\section{Materials and Methods}

\section{General procedures}

NMR spectra were recorded at $25^{\circ} \mathrm{C}$ on a Varian Gemini 2000 or a Bruker AMX 400 spectrometer (proton frequency 300.07 and $400.13 \mathrm{MHz}$, respectively), with $\mathrm{CDCl}_{3}$ as solvent and TMS as internal standard, using standard library pulse sequences.

Planta Med 66 (2000) 531-536

(C) Georg Thieme Verlag Stuttgart · New York ISSN: 0032-0943
NOESY spectra were obtained with mixing times of $500-$ $900 \mathrm{~ms}$. HMBC spectra were optimized for ${ }^{n} J_{\mathrm{CH}_{3}}$ of $4-11 \mathrm{~Hz}$. Mass spectra were obtained on a JEOL JMS-AX505W double focussing spectrometer with EI or FAB ionization (positive ion mode). Column chromatography was performed on silica gel 60 (Merck, $0.063-0.2 \mathrm{~mm}$ ). Fractions were monitored by TLC (Merck precoated silica gel $60 \mathrm{~F}_{254}$ plates), using UV light and Dragendorff reagent to visualize the spots. Preparative HPLC was carried out on a $250 \times 16 \mathrm{~mm}$ Knauer column packed with LiChrospher-100 RP18, $5 \mu \mathrm{m}$, using a Waters system consisting of a model 590 pump and a model 481 UV spectrophotometer operating at $225 \mathrm{~nm}$. Compounds 6-8 were obtained from commercial sources, whereas $\mathbf{9}$ and $\mathbf{1 0}$ were synthetic, racemic compounds (14); the identity and purity of all materials was confirmed by ${ }^{1} \mathrm{H}-\mathrm{NMR}$ spectroscopy.

\section{Plant material}

C. pachyceras K. Schum. was identified and its bark collected by Mr. D. K. Abbiw, Department of Botany, University of Ghana, near Agriculture Research Station, Kede, South Ghana. A voucher specimen was deposited in Ghana Herbarium (GC 47529).

\section{Extraction and isolation}

Powdered stem bark ( $250 \mathrm{~g})$ was macerated three times with 11 of $\mathrm{CH}_{2} \mathrm{Cl}_{2}-\mathrm{MeOH}(1: 1)$ to give a total of $47 \mathrm{~g}$ of raw extract. The extract was partitioned between light petroleum, EtOAc and $\mathrm{H}_{2} \mathrm{O}$, and the fractions tested for antileishmanial and antimalarial activity. The activity was confined to the EtOAc fraction, which was subjected to open column chromatography (silica gel, stepwise gradient elution from $\mathrm{CH}_{2} \mathrm{Cl}_{2}$ to EtOAc to $\mathrm{MeOH}$ ). The activity was present in alkaloid-containing fractions (Dragendorff reagent). A portion (182 mg) of the combined alkaloid fraction $(6.34 \mathrm{~g})$ was subjected to preparative $\mathrm{HPLC}\left(6 \mathrm{ml} / \mathrm{min}\right.$ of $70 \% \mathrm{MeOH}$ in $0.01 \mathrm{M}$ aq. $\left.\mathrm{AcONH}_{4}, \mathrm{pH} 8.04\right)$, to give, in the order of elution, $16.6 \mathrm{mg}$ of $1,2.1 \mathrm{mg}$ of $\mathbf{2}$, $10.3 \mathrm{mg}$ of $\mathbf{3}, 6.3 \mathrm{mg}$ of $\mathbf{4}$, and $9.2 \mathrm{mg}$ of $\mathbf{5}$.

Corynanthine (1): Colorless oil; $[\alpha]_{D}^{20}:-76.5^{\circ}$ (c 0.38, pyridine), lit. (2) $-73^{\circ}$ (pyridine); HREIMS: $m / z=353.1875\left([\mathrm{M}-\mathrm{H}]^{+}\right.$), $\mathrm{C}_{21} \mathrm{H}_{25} \mathrm{~N}_{2} \mathrm{O}_{3}$ requires 353.1865 . Content in the bark $0.23 \%$.

$\alpha$-Yohimbine (2): Colorless oil; $[\alpha]_{D}^{20}:-17^{\circ}$ (c 1.38, pyridine), lit. (3) $-18^{\circ}$ (pyridine); HRFABMS: $m / z=355.2044\left([\mathrm{M}+\mathrm{H}]^{+}\right.$), $\mathrm{C}_{21} \mathrm{H}_{27} \mathrm{~N}_{2} \mathrm{O}_{3}$ requires 355.2022 . Content in the bark $0.03 \%$. 
Dihydrocorynantheine (3): Colorless oil; $[\alpha]_{\mathrm{D}}^{20}:+25^{\circ}$ (c 0.67, $\mathrm{MeOH}$ ), lit. (4) $+36.2^{\circ}(\mathrm{MeOH})$; HRFABMS: $m / z=369.2155$ ([M $\left.+\mathrm{H}]^{+}\right), \mathrm{C}_{22} \mathrm{H}_{29} \mathrm{~N}_{2} \mathrm{O}_{3}$ requires 369.2178. Content in the bark $0.15 \%$.

Corynantheine (4): Colorless oil; $[\alpha]_{\mathrm{D}}^{20}:+32^{\circ}($ c 1.10, MeOH), lit. $(5)+28.5^{\circ}(\mathrm{MeOH})$; HRFABMS: $m / z=367.1973\left([\mathrm{M}+\mathrm{H}]^{+}\right)$, $\mathrm{C}_{22} \mathrm{H}_{27} \mathrm{~N}_{2} \mathrm{O}_{3}$ requires 367.2022 . Content in the bark $0.09 \%$.

Corynantheidine (5): Colorless oil; $[\alpha]_{\mathrm{D}}^{20}:-181^{\circ}(c 7.41, \mathrm{MeOH})$, lit. (6) $-171^{\circ}(\mathrm{MeOH})$; HRFABMS: $m / z=369.2137\left([\mathrm{M}+\mathrm{H}]^{+}\right)$, $\mathrm{C}_{22} \mathrm{H}_{29} \mathrm{~N}_{2} \mathrm{O}_{3}$ requires 369.2178 . Content in the bark $0.13 \%$.

\section{Assay for antiplasmodial activity}

A modification of Desjardins' radioisotope method (7) for measuring growth of a chloroquine sensitive strain of Plasmodium falciparum (3D7) was adopted, using uptake of $\left[{ }^{3} \mathrm{H}\right]$ phenylalanine as an index of growth. Thus, $50 \mu \mathrm{l}$ of the growth medium (RPMI 1640 added 5\% Albumax, $5.95 \mathrm{~g} / 1$ of HEPES, $31 \mathrm{ml} / \mathrm{l}$ of $7.5 \%$ sodium bicarbonate, and $500 \mathrm{mg} / \mathrm{l}$ of glucose) containing test substances added from a DMSO stock were mixed with a suspension of parasitic erythrocytes (5\% hematocrit, $2-3 \%$ parasitemia) in 96 -well microtiter plates. The maximal final DMSO concentration was $0.5 \%$. Each concentration of the test substance was tested in triplicate. The plates were incubated at $37^{\circ} \mathrm{C}$ for 24 hours before the addition of $\left[{ }^{3} \mathrm{H}\right]$ phenylalanine. After an additional 24 hours incubation period, the parasites were harvested and incorporation of radioactivity determined by liquid scintillation counting.

\section{Assay for leishmanicidal activity}

Promastigotes from a WHO reference vaccine strain of Leishmania major were maintained at $26^{\circ} \mathrm{C}$ in RPMI 1640 medium containing $25 \mathrm{mM}$ HEPES, $4 \mathrm{mM}$ L-glutamine, $0.02 \mathrm{mg} / \mathrm{ml}$ of gentamicin, and $10 \%$ of heat-inactivated fetal calf serum. The effect of plant extract and pure compounds on the growth of promastigotes was assessed by monitoring inhibition of $\left[{ }^{3} \mathrm{H}\right]$ thymidine uptake similarly as previously described (8). The compounds for testing were dissolved in DMSO, the stock solution diluted appropriately with the growth medium, and aliquots incubated in 96-well microtiter plates with promastigotes $\left(1 \times 10^{7}\right.$ per $\mathrm{ml}, 180 \mu \mathrm{l} /$ well $)$ for 2 hours. After addition of $\left[{ }^{3} \mathrm{H}\right]$ thymidine the plates were incubated for 18 hours, the cells harvested, and the incorporation of radioactivity determined by liquid scintillation counting.

\section{Assay for cytostatic activity}

Mycoplasma-free carcinoma cell lines KB-3-1 (a HeLa subclone) and $K B-V 1$, selected for resistance with vinblastine from the KB-3-1 cells (9), were obtained from the Laboratory of Cell Biology, National Cancer Institute, National Institutes of Health, Bethesda, Maryland, USA. The cells were maintained in monolayers at $37{ }^{\circ} \mathrm{C}$ in an atmosphere containing $5 \%$ $\mathrm{CO}_{2}$ (humidity $98 \%$ ), using Dulbecco's modified Eagle medium (DMEM) containing 10\% fetal bovine serum, glucose $(4.5 \mathrm{~g} / \mathrm{l})$, L-glutamine $(0.58 \mathrm{~g} / \mathrm{l})$, sodium pyruvate $(1 \mathrm{mM})$, penicillin (100 units $/ \mathrm{ml}$ ) and streptomycin $(100 \mu \mathrm{g} / \mathrm{ml})$. The KB-V1 cells were grown in the absence of cytostatic pressure from vinblastine, but the cells from passage number 5-15 preserved unchanged degree of resistance to rhodamine 123 (10), and were used in the assay. For the cytotoxicity assays, the KB-3-1 cells $(70-80 \%$ confluency) or the KB-V1 cells $(60-70 \%$ confluency) were harvested by trypsinization, applied into 96 well plates $\left(4 \times 10^{3}\right.$ of KB-3-1 cells or $7 \times 10^{3}$ of KB-V1 cells per well) in $75 \mu \mathrm{l}$ of the culture medium, and grown for 24 hours. Test substances were applied in $75 \mu \mathrm{l}$ of a solution prepared by mixing $50 \mu \mathrm{l}$ of a DMSO stock with $0.950 \mathrm{ml}$ of the medium and appropriately diluted with the medium to required concentrations; thus, no well contained more than $0.25 \%$ of DMSO, which was also present in the control wells. Six wells were used for each concentration of the test substance. Time of incubation and the amounts of the cells used were such that the cells in the control wells reached $70 \%$ (KB$3-1$ ) or $60-70 \%$ (KB-V1) confluency at the end of the 72 hours incubation period. After the incubation the medium was removed and the amount of cells was determined using the CellTiter 96 aqueous cell proliferation assay kit from Promega Corporation. The MTS/PMS reagent (11) was freshly prepared by mixing $2.0 \mathrm{ml}$ MTS solution $(2 \mathrm{mg} / \mathrm{ml})$ with $99.4 \mu \mathrm{l}$ PMS solution $(0.92 \mathrm{mg} / \mathrm{ml}$ ) and $10.4 \mathrm{ml}$ of growth medium (without phenol red and serum). After addition of $120 \mu \mathrm{l}$ of the reagent mixture to each well, the plate was incubated for $50 \mathrm{~min}$ and the absorbance determined at $490 \mathrm{~nm}$. The reported $\mathrm{IC}_{50}$ values are the result of three separate determinations with different passages of the cells.

\section{Results and Discussion}

Crude ethanolic extracts of $C$. pachyceras bark strongly inhibited growth of Plasmodium falciparum and of Leishmania major promastigotes. Fractionation of the extract on silica gel showed that the activity was confined to fractions which gave a positive reaction with the Dragendorff reagent. Individual constituents of the alkaloid fraction were separated by preparative, reversed-phase HPLC using a mixture of methanol and ammonium acetate buffer. Optimization of the HPLC system showed that the separation was improved with increasing $\mathrm{pH}$, and baseline separation was achieved at $\mathrm{pH}$ 8.04. Five indole alkaloids were isolated in amounts corresponding to the total alkaloid content in the plant material of $0.63 \%$.

Compounds 1 and 2 (Fig. 1) were isomers with the molecular formula $\mathrm{C}_{21} \mathrm{H}_{26} \mathrm{~N}_{2} \mathrm{O}_{3}$ as determined by HRMS. ${ }^{13} \mathrm{C}$-NMR spectra indicated the presence of a yohimboid skeleton (12). Analysis of coupling patterns, supported by COSY and NOESY experiments, led to identification of the stereochemistry as $3 \alpha, 15 \alpha, 20 \beta$ (normal configuration) for 1 and as $3 \alpha, 15 \alpha, 20 \alpha$ (allo configuration) for 2 . Furthermore, both compounds have $\mathrm{H}-16$ in the $\alpha$-configuration and $\mathrm{H}-17$ in the $\beta$-configuration. The compounds $\mathbf{1}$ and $\mathbf{2}$ thus correspond to corynanthine and $\alpha$-yohimbine, respectively. Compounds $\mathbf{3}$ and $\mathbf{5}$ were isomers with the molecular formula $\mathrm{C}_{22} \mathrm{H}_{28} \mathrm{~N}_{2} \mathrm{O}_{3}$ (HRMS). ${ }^{13} \mathrm{C}$-NMR spectra showed the presence of a corynantheine-type structure (13). The stereochemistry of the corynene skeleton in $\mathbf{5}$ was established as $3 \alpha, 15 \alpha, 20 \alpha ; 5$ is thus corynantheidine. Compound 3 showed broadened resonances in the $400 \mathrm{MHz}$ ${ }^{1} \mathrm{H}-\mathrm{NMR}$ spectrum, indicating the presence of several conformers in slow exchange on the NMR time scale, but the alkaloid could be unambiguously identified as dihydrocorynantheine by comparison of its ${ }^{1} \mathrm{H}$ - and ${ }^{13} \mathrm{C}-\mathrm{NMR}$ spectra with those of an original sample of synthetic (14), racemic dihydrocorynantheine. Compound $\mathbf{4}$ was identified as an unsaturated analogue of $\mathbf{3}$, corynantheine (13) 


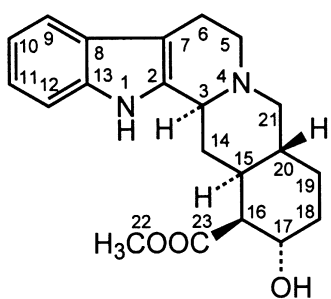

1

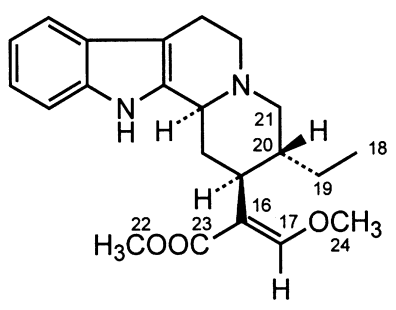

3<smiles>CC(=O)[C@H]1[C@@H](O)CC[C@@H]2CN3CCc4c([nH]c5ccccc45)[C@H]3C[C@H]21</smiles>

2<smiles>C=C[C@H]1CN2CCc3c([nH]c4ccccc34)[C@H]2C[C@H]1/C=C\OC</smiles>

4<smiles>CC[C@H]1CN2CCc3c([nH]c4ccccc34)[C@H]2C[C@H]1/C(C=O)=C\OC</smiles>

5
Fig. 1 Structures of indole alkaloids isolated from Corynanthe pachyceras: $\mathbf{1}$, corynanthine; $\mathbf{2}, \alpha$-yohimbine; $\mathbf{3}$, dihydrocorynantheine; 4, corynantheine; $\mathbf{5}$, corynantheidine.

The ${ }^{13} \mathrm{C}-\mathrm{NMR}$ data for $\mathbf{1 - 5}$ (Fig. 1) are given in Table $\mathbf{1}$. On the basis of ${ }^{1} \mathrm{H},{ }^{13} \mathrm{C}$ chemical shift correlation experiments, the assignments of $\mathrm{C}-10$ and $\mathrm{C}-11$ in $\mathbf{3 - 5}$ were reversed as compared to the earlier reports (13), (15). The original literature assignments were apparently based on a previous (16), erroneous assignment of C-5 and C-6 in indole, which persisted in the literature for a long time before being corrected (17), (18). The assignments in Table $\mathbf{1}$ are based on HMQC experiments and are in agreement with those recently published for synthetic rac-5 (19). The fully assigned ${ }^{1} \mathrm{H}-\mathrm{NMR}$ data for $\mathbf{1 - 5}$, not reported previously, are shown in Table 2.

Pure indole alkaloids 1-5 were tested in vitro for antileishmanial, antimalarial and cytotoxic activity. The results are shown in Table 3. The leishmanicidal activity was assessed using L. major promastigote cultures and compared with that of antimony (V) sodium gluconate (sodium stibogluconate, Pentostam), which is the recommended drug for the treatment of leishmaniasis, but is rather inactive in this in vitro test. The antimalarial activity was assessed with a chloroquine-sensitive strain of P.falciparum. Assay for cytotoxicity included growth inhibition of two carcinoma cell lines, a drug sensitive $\mathrm{KB}-3-1$ cell line and a multidrug resistant KB-V1 cell line. The $\mathrm{KB}-\mathrm{V} 1$ cells display the complete multidrug-resistance phenotype including the expression of the P-170 glycoprotein (9), (20), (21).
Table $1{ }^{13} \mathrm{C}$-NMR data $\left(\mathrm{CDCl}_{3}\right)$ for $\mathrm{C}$. pachyceras alkaloids.

\begin{tabular}{lrrrrr}
\hline & \multicolumn{1}{l}{$\mathbf{1}$} & \multicolumn{1}{l}{$\mathbf{l}$} & \multicolumn{1}{l}{$\mathbf{3}$} & \multicolumn{1}{l}{$\mathbf{5}$} \\
\hline C-2 & 134.6 & 134.5 & 135.3 & 135.2 & 135.9 \\
C-3 & 60.4 & 60.3 & 60.4 & 60.1 & 61.4 \\
C-5 & 52.9 & 53.3 & 53.3 & 52.9 & 53.6 \\
C-6 & 21.5 & 21.8 & 22.6 & 21.8 & 21.9 \\
C-7 & 108.0 & 108.5 & 108.0 & 108.0 & 108.3 \\
C-8 & 127.4 & 127.3 & 127.6 & 127.6 & 127.8 \\
C-9 & 118.2 & 118.1 & 118.3 & 118.3 & 118.3 \\
C-10 & 119.4 & 119.5 & 119.5 & 119.5 & 119.5 \\
C-11 & 121.3 & 121.5 & 121.4 & 121.4 & 121.3 \\
C-12 & 110.9 & 110.8 & 111.0 & 111.0 & 110.9 \\
C-13 & 136.0 & 136.0 & 136.3 & 136.3 & 136.2 \\
C-14 & 33.6 & 27.7 & 33.9 & 33.4 & 29.9 \\
C-15 & 36.9 & 38.0 & 38.9 & 38.8 & 40.8 \\
C-16 & 51.1 & 54.8 & 111.9 & 111.7 & 111.7 \\
C-17 & 67.0 & 66.1 & 160.3 & 160.2 & 160.9 \\
C-18 & 28.5 & 33.1 & 11.3 & 115.7 & 12.9 \\
C-19 & 23.7 & 24.6 & 24.4 & 139.6 & 19.1 \\
C-20 & 34.9 & 36.6 & 39.3 & 42.9 & 40.0 \\
C-21 & 62.1 & 60.6 & 61.8 & 61.4 & 57.9 \\
C-22 & 51.4 & 52.0 & 51.5 & 51.4 & 51.5 \\
C-23 & 172.5 & 174.7 & a & 169.5 & 169.6 \\
C-24 & & & 61.0 & 61.7 & 61.7 \\
\hline
\end{tabular}

a Not detectable due to exchange-broadening.

Since no previous reports about leishmanicidal activity of yohimbine- and corynantheine-type alkaloids exist, several structurally related alkaloids were included in the test. These include reserpine (6), ajmalicine (7), ajmaline (8), as well as two synthetic, racemic compounds rac-9 and rac-10 (Fig. 2) (14). The leishmanicidal activity of $\mathbf{3 - 5}, \mathbf{7}$, rac-9 and rac-10 corresponded to $\mathrm{IC}_{50}$ values below $3 \mu \mathrm{M}$ (Table 3 ). Interestingly, ajmaline (8) was inactive against L. major promastigotes, suggesting that the active alkaloids should contain a relatively planar tetracyclic structure.

The antimalarial activity exhibited by the compounds tested was rather low (Table 3 ). The most active of the alkaloids tested was reserpine (6). However, it should be noted that the three alkaloids with the corynene skeleton 3-5 were significantly more toxic to $P$. falciparum than the yohimbine-type alkaloids $\mathbf{1}$ and $\mathbf{2}$. The activity of rac-9 and rac-10 was also higher than that of $\mathbf{1}$ and $\mathbf{2}$. There was no difference in the antiplasmodial activity of $\mathbf{3}$ and rac-3, showing that the eudismic index for dihydrocorynantheine is close to unity. On the other hand, a small difference in the $\mathrm{IC}_{50}$ values for the leishmanicidal activity between $\mathbf{3}$ and rac-3 suggests that the natural, dextrorotatory $\mathbf{3}$ is somewhat more potent than its enantiomer.

None of the alkaloids isolated from C.pachyceras exhibited significant cytotoxicity (Table 3 ). This confirms that the leishmanicidal activity exhibited by these alkaloids is not due to a general antiproliferative effect. The toxicity of 1-5 to the drug-sensitive KB-3-1 cells and the multidrug-resistant KB$\mathrm{V} 1$ cells was identical. The resistance of the KB-V1 cells relative to the KB-3-1 cells is 210 -fold for vinblastine and even 
Table $2{ }^{1} \mathrm{H}$-NMR data $\left(\mathrm{CDCl}_{3}\right)$ for $\mathrm{C}$. pachyceras alkaloids (coupling constants given as numberic values in $\mathrm{Hz}$ ).

\begin{tabular}{|c|c|c|c|c|c|}
\hline & 1 & 2 & 3 & 4 & 5 \\
\hline $\mathrm{H}-1$ & 7.87 & 7.73 & 7.99 & 7.87 & 7.79 \\
\hline \multirow[t]{2}{*}{$\mathrm{H}-3$} & 3.26 & 3.15 & a & 3.29 & 3.18 \\
\hline & $3 / 3,14 \mathrm{ax}=11.6$ & ${ }^{3} / 3,14 \mathrm{ax}=12.6$ & & $3 / 3,14 \mathrm{ax}=10.5$ & $3 / 3,14 \mathrm{ax}=11.3$ \\
\hline$H-5$ & $2.58(\mathrm{ax}), 3.07$ (eq) & 2.51 (ax), 3.07 (eq) & a & 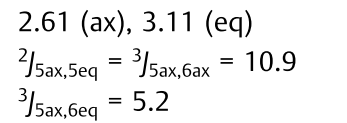 & $2.58(\mathrm{ax}), 2.96(\mathrm{eq})$ \\
\hline H-6 & $\begin{array}{l}3.00(\mathrm{ax}), 2.70(\mathrm{eq}) \\
{ }^{2} J_{6 \mathrm{eq}, 6 \mathrm{bax}}=15.0,{ }^{3} J_{6 \mathrm{eq}, 5 \mathrm{ax}}=3.5, \\
{ }^{3} J_{6 \mathrm{eq}, 5 \mathrm{eq}}=1.5\end{array}$ & $2.92(\mathrm{ax}), 2.68(\mathrm{eq})$ & a & $3.04(\mathrm{ax}), 2.72(\mathrm{eq})$ & 2.95 (ax), 2.72 (eq) \\
\hline \multirow[t]{2}{*}{$\mathrm{H}-9$} & 7.48 & 7.46 & 7.45 & 7.46 & 7.46 \\
\hline & $3 J_{9,10}=7.8$ & $3 \int_{9,10}=7.6$ & $3 \int_{9,10}=7.1$ & ${ }^{3} \int_{9,10}=7.1,{ }^{4} \int_{9,11}=1.5$ & $3 \int_{9,10}=7.3,4 J_{9,11}=1.5$ \\
\hline \multirow[t]{2}{*}{$\mathrm{H}-10$} & 7.09 & 7.08 & 7.00 & 7.07 & 7.06 \\
\hline & $3^{3} / 10,11=7.8$ & $\begin{array}{l}3 J_{10,11}=1.6 \\
4 J_{10,12}=1.2\end{array}$ & $\begin{array}{l}3_{10,11}=7.1 \\
4_{10,12}=1.4\end{array}$ & $\begin{array}{l}3 J_{10,11}=7.1 \\
4 J_{10,12}=1.5\end{array}$ & $\begin{array}{l}3_{10,11}=1.3 \\
4_{10,12}=1.5\end{array}$ \\
\hline \multirow[t]{2}{*}{$\mathrm{H}-11$} & 7.18 & 7.13 & 7.11 & 7.11 & 7.11 \\
\hline & $3 / 11,12=7.8$ & $\begin{array}{l}3 \int_{11,12}=7.6 \\
4 \int_{11,9}=1.2\end{array}$ & $\begin{array}{l}3 \int_{11,12}=7.1 \\
4 J_{11,9}=1.4\end{array}$ & $3 / 11,12=7.1$ & $3 / 11,12=7.3$ \\
\hline $\mathrm{H}-12$ & 7.36 & 7.30 & 7.29 & 7.26 & 7.29 \\
\hline \multirow{2}{*}{$\mathrm{H}-14$} & $1.42(\mathrm{ax}), 1.68(\mathrm{eq})$ & $1.71(\mathrm{ax}), 1.60(\mathrm{eq})$ & a & $2.11(\mathrm{ax}), 1.97(\mathrm{eq})$ & $2.52(a x), 1.83$ (eq) \\
\hline & $\begin{array}{l}3 \int_{15,14 \mathrm{eq}}=11.6 \\
3 \int_{14 \mathrm{ax}, 15}=3.8\end{array}$ & $\begin{array}{l}\int_{14 \mathrm{ax}, 14 \mathrm{eq}}=3 \int_{14 \mathrm{ax}, 15}=12.6 \\
3 \int_{14 \mathrm{eq}, 3}=3 \int_{14 \mathrm{eq}, 15}=3.8\end{array}$ & & $\begin{array}{l}\int_{14 \mathrm{ax}, 14 \mathrm{eq}}=3 \int_{14 \mathrm{ax}, 15}=12.1, \\
3 J_{14 \mathrm{eq}, 3}=3 \int_{14 \mathrm{eq}, 15}=3.4\end{array}$ & $\begin{array}{l}2 \int_{14 \text { eq, } 14 a x}=13.1, \\
3 J_{14 \text { eq, } 3}=3 / J_{14 \text { eq, }, 15}=2.5\end{array}$ \\
\hline \multirow[t]{2}{*}{$\mathrm{H}-15$} & 1.88 & 2.44 & a & 2.77 & 3.05 \\
\hline & $\begin{array}{l}3 / 15,20=11.6 \\
3 / 15,16=3.8\end{array}$ & ${ }^{3} J_{15,16}=3 J_{15,20}=3.8$ & & $3_{15,20}=11.8$ & \\
\hline $\mathrm{H}-16$ & 2.61 & 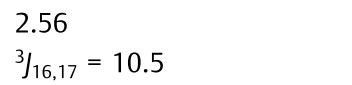 & - & - & - \\
\hline $\mathrm{H}-17$ & $\begin{array}{l}4.19 \\
3 / 17,16=3 J_{17,18 \mathrm{ax}} \\
=3 J_{17,18 \mathrm{eq}}=2.5\end{array}$ & $\begin{array}{l}4.00 \\
3 \int_{17,18 \mathrm{ax}}=11.0 \\
3 J_{17,18 \mathrm{eq}}=4.5\end{array}$ & 7.37 & 7.33 & 7.43 \\
\hline $\mathrm{H}-18$ & $1.73(\mathrm{ax}), 2.12(\mathrm{eq})$ & $\begin{array}{l}1.37(\mathrm{ax}), 2.06(\mathrm{eq}) \\
2 \int_{18 \mathrm{ax}, 18 \mathrm{eq}}=3 / 18 \mathrm{ax}, 19 \mathrm{ax}=13.5, \\
3 J_{18 \mathrm{ax}, 19 \mathrm{eq}}=4.0\end{array}$ & a & $\begin{array}{l}4.95\left(\mathrm{H}_{\mathrm{E}}\right), 5.04\left(\mathrm{H}_{\mathrm{Z}}\right) \\
3_{18 \mathrm{E}, 19}=10.3,{ }^{2} \mathrm{~J}_{18 \mathrm{E}, 18 \mathrm{Z}}= \\
2.0,{ }^{3} \mathrm{~J}_{18 \mathrm{Z}, 19}=17.3, \\
{ }^{4} \mathrm{~J}_{18 \mathrm{Z}, 20}=0.7\end{array}$ & $\begin{array}{l}0.95 \\
3 / 18,19=7.0\end{array}$ \\
\hline $\mathrm{H}-19$ & $1.43(\mathrm{ax}, \mathrm{eq})$ & $\begin{array}{l}2.10(\mathrm{ax}), 1.56(\mathrm{eq}) \\
2 \int_{19 \mathrm{ax}, 19 \mathrm{eq}}=3 \int_{19 \mathrm{ax}, 20}=13.5, \\
3 \int_{19 \mathrm{ax}, 18 \mathrm{eq}}=3 \int_{19 \mathrm{eq}, 18 \mathrm{eq}}= \\
3 \int_{19 \mathrm{eq}, 20}=4.0\end{array}$ & a & $\begin{array}{l}5.58 \\
3 / 19,20=8.2\end{array}$ & $1.76,1.20$ \\
\hline $\mathrm{H}-20$ & $\begin{array}{l}2.04 \\
3 \int_{20,19 \mathrm{ax}}=3 / 20,21 \mathrm{ax}=11.6, \\
3 \int_{20,19 \mathrm{eq}}=3 \int_{20,21 \mathrm{eq}}=3.4\end{array}$ & 1.82 & a & 3.07 & 1.63 \\
\hline $\mathrm{H}-21$ & $\begin{array}{l}2.09(\mathrm{ax}), 2.95(\mathrm{eq}) \\
2 J_{21 \mathrm{ax}, 21 \mathrm{eq}}=10.6\end{array}$ & $\begin{array}{l}2.59(\mathrm{ax}), 2.85(\mathrm{eq}) \\
2 \mathrm{~J}_{21 \mathrm{ax}, 21 \mathrm{eq}}=11.5,3 \mathrm{~J}_{21 \mathrm{ax}, 20}= \\
3.3,3 \mathrm{~J}_{21 \mathrm{eq}, 20}=2.1\end{array}$ & a & $\begin{array}{l}2.31(\mathrm{ax}), 3.05(\mathrm{eq}) \\
2 J_{21 \mathrm{ax}, 21 \mathrm{eq}}=3 / 21 \mathrm{ax}, 20=12.8\end{array}$ & $\begin{array}{l}2.48(\mathrm{ax}), 3.02(\mathrm{eq}) \\
2 \int_{21 \mathrm{ax}, 21 \mathrm{eq}}=11.0 \\
3 \int_{21 \mathrm{ax}, 20}=2.0\end{array}$ \\
\hline $\mathrm{H}-22$ & 3.56 & 3.84 & a & 3.69 & 3.71 \\
\hline $\mathrm{H}-24$ & - & - & a & 3.75 & 3.72 \\
\hline
\end{tabular}

a Not assigned due to exchange-broadening.

higher for other cytotoxic drugs (9), (10). This indicates that the Corynanthe alkaloids, unlike many other alkaloids including Catharanthus alkaloids, are not substrates for the P-170 efflux pump.

Since pentavalent antimony complexes are the only antileishmanial agents with a clearly favorable therapeutic index, there is a high interest in identification of alternative chemotherapeutic leads. The alkaloids identified in this work as antileishmanial compounds with their $\mathrm{IC}_{50}$ values of $1 \mu \mathrm{M}$ or below (Table 3 ) belong to the most potent natural products showing leishmanicidal activity in similar in vitro assays (2226). At present, there is no basis for a conclusion about mechanism of the leishmanicidal effects of these alkaloids. 
Table 3 Antileishmanial, antimalarial and cytotoxic activity of $C$. pachyceras alkaloids and related compounds.

\begin{tabular}{|c|c|c|c|c|}
\hline \multirow[t]{2}{*}{ Compound } & \multirow[b]{2}{*}{ L. major } & \multicolumn{2}{|c|}{$\mathrm{IC}_{50}(\mu \mathrm{M})$} & \multirow[b]{2}{*}{$\mathrm{KB}-\mathrm{VI}$} \\
\hline & & P. falciparum & KB-3-1 & \\
\hline corynanthine (1) & $23.4 \pm 5.4$ & $>200$ & $186 \pm 1$ & $214 \pm 26$ \\
\hline$\alpha$-yohimbine (2) & $23.8 \pm 2.6$ & $>200$ & $200 \pm 23$ & $263 \pm 12$ \\
\hline dihydrocorynantheine (3) & $1.65 \pm 0.3$ & $66.4 \pm 6.5$ & $161 \pm 19$ & $158 \pm 15$ \\
\hline corynantheine (4) & $1.12 \pm 0.4$ & $81.1 \pm 1.6$ & $140 \pm 11$ & $144 \pm 4$ \\
\hline corynantheidine (5) & $2.81 \pm 0.4$ & $41.1 \pm 2.5$ & $80 \pm 8$ & $80 \pm 5$ \\
\hline reserpine $(\mathbf{6})$ & $16.4 \pm 2.3$ & $8.1 \pm 0.4$ & - & - \\
\hline ajmalicine (7) & $0.57 \pm 0.1$ & $>200$ & - & - \\
\hline ajmaline (8) & $>300$ & $121 \pm 9$ & - & - \\
\hline rac-9 & $0.71 \pm 0.2$ & $132 \pm 1$ & - & - \\
\hline rac-10 & $1.51 \pm 0.1$ & $68 \pm 12$ & - & - \\
\hline rac-3 & $2.80 \pm 0.43$ & $77.2 \pm 4.1$ & - & - \\
\hline Pentostam & $219 \pm 25$ & - & - & - \\
\hline Chloroquine & - & $0.00130 \pm 0.00005$ & - & - \\
\hline Rhodamine-123 & - & 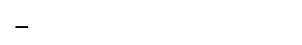 & $1.0 \pm 0.3$ & $>500$ \\
\hline
\end{tabular}<smiles>COC(=O)O[C@H]1C[C@@H]2CN3CCc4c([nH]c5cc(OC)ccc45)[C@]3(C2)[C@H]2C[C@H](C(C)=O)[C@H](O)[C@H]12</smiles>

6

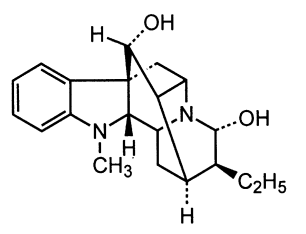

8

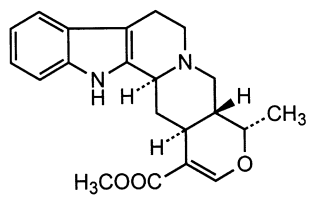

7

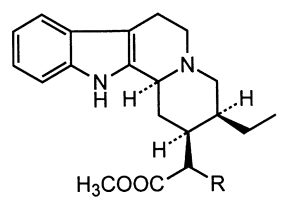

$9 \mathrm{R}=\mathrm{H}$ $10 \mathrm{R}=\mathrm{COOCH}_{3}$

Fig. 2 Structures of indole alkaloids tested for leishmanicidal and antiplasmodial activity: $\mathbf{6}$, reserpine; 7 , ajmalicine; 8 , ajmaline; 9 and $\mathbf{1 0}$, synthetic compounds.

However, it should be noted that ajmalicine (7) is an extremely potent inhibitor of the 2D6 subfamily of cytochrome P450 (27). Whether or not the observed high activity of 7 and the isolated C. pachyceras alkaloids (Table $\mathbf{3}$ ) is related to an inhibition of the respiratory chain of $L$. major has yet to be determined.

\section{Acknowledgements}

We are indebted to Mr. Daniel K. Abbiw, Department of Botany, University of Ghana, for collection and identification of the plant material used in this work. We also thank Dr. Istvan Toth, School of Pharmacy, University of London, for samples of synthetic 3, 9 and 10.

\section{References}

${ }^{1}$ Abbiw D. Useful Plants of Ghana. Kew: Intermediate Technology Publications and The Royal Botanic Gardens, 1990

2 Janot MM, Goutarel R. La corynanthine; ses rapports de constitution avec la yohimbine. Bull. Soc. Chim. Fr. 1949; 509-15

${ }^{3}$ Le Hir A, Janot M-M, Goutarel R. Stéréoisoméres de la yohimbine; allo-yohimbine et $\alpha$-yohimbine. Bull. Soc. Chim. Fr. 1953; $1027-$ 32

${ }^{4}$ Merlini L, Mendelli R, Nasini G, Hesse M. Gambirine, a new alkaloid from Uncaria gambier Roxb. Tetrahedron Lett. 1967; 16 : $1571-4$

${ }^{5}$ Goutarel R, Janot M-M, Mirza R, Prelog V. Über das reine Corynanthein. Helv. Chim. Acta. 1953; 36: 337-40

${ }^{6}$ Janot M-M, Goutarel R, Chabasse-Massonneau J. Structure de la corynanthéidine. Bull. Soc. Chim. Fr. 1953; 1033-8

${ }^{7}$ Desjardins RE, Canfield CJ, Haynes JD, Chulay JD. Quantitative assessment of antimalarial activity in vitro by a semiautomated microdilution technique. Antimicrob. Agents Chemother. 1979; 16: 710-8

${ }^{8}$ Chen M, Christensen SB, Blom J, Lemmich E, Nadelmann L, Fich K, et al. Licochalcone $A$, a novel antiparasitic agent with potent activity against human pathogenic protozoan species of Leishmania. Antimicrob. Agents Chemother. 1993; 37: 2550-6

${ }^{9}$ Shen DW, Cardarelli C, Hwang J, Cornwell M, Richert N, Ishii S, et al. Multiple drug-resistant human KB carcinoma cells independently selected for high-level resistance to colchicine, adriamycin, or vinblastine show changes in expression of specific proteins. J. Biol. Chem. 1986; 261: $7762-70$

${ }^{10}$ Kaplan O, Jaroszewski JW, Clarke R, Fairchild CR, Schoenlein P, Goldenberg S, et al. The multidrug resistance phenotype: ${ }^{31} \mathrm{P}$ nuclear magnetic resonance characterization and 2-deoxyglucose toxicity. Cancer Res. 1991; 51: $1638-44$

${ }^{11}$ Cory AH, Owen TC, Barltrop JA, Cory JG. Use of aqueous soluble tetrazolium/formazan assay for cell growth assays in culture. Cancer Commun. 1991; 3: 207-12

${ }^{12}$ Wenkert E, Chang C-J, Chawla HPS, Cochran DW, Hagaman EW, King JC, et al. General methods of synthesis of indole alkaloids. 14. Short routes of construction of yohimboid and ajmalicinoid alkaloid systems and their ${ }^{13} \mathrm{C}$ nuclear magnetic resonance spectral analysis. J. Am. Chem. Soc. 1976; 98: 3645-55 
${ }^{13}$ Wenkert E, Bindra JS, Chang C-J, Cochran DW, Schell FM. Carbon13 nuclear magnetic resonance spectroscopy of naturally occurring substances. Alkaloids. Acc. Chem. Res. 1974; 7: 46-51

${ }^{14}$ Barczai-Beke M, Dörnyei G, Toth G, Tamas J, Szantay C. Synthesis of corynantheidine alkaloids - III. The stereoselective total synthesis of ( \pm )-dihydrocorynantheine. Tetrahedron 1976; 32: 1153 9

${ }^{15}$ Goh SH, Junan SAA. Alkaloids of Uncaria callophylla. Phytochemistry $1985 ; 24: 880-1$

${ }^{16}$ Parker RG, Roberts JD. Nuclear magnetic resonance spectroscopy. ${ }^{13} \mathrm{C}$ spectra of indole and methylindoles. J. Org. Chem. 1970; 35: 996-9

${ }^{17}$ Brennan MR, Erickson KL, Szmalc FS, Tansey MJ, Thornton JM. The preparation and spectral characterization of 2-haloindoles, 3-haloindoles, and 2,3-dihaloindoles. Heterocycles 1986; 24: 2879-85

${ }^{18}$ Burton G, Ghini AA, Gros EG. ${ }^{13} \mathrm{C}$ NMR spectra of substituted indoles. Magn. Reson. Chem. 1986; 24: 829-31

${ }^{19}$ Lounasmaa M, Jokela R, Laine C, Hanhinen P. Short, stereospecific total synthesis of $( \pm)$-corynantheidine. Tetrahedron Lett. 1995; 36: $8687-8$

20 Ueda K, Cornwell MM, Gottesman MM, Pastan I, Roninson IB, Ling $\mathrm{V}$, et al. The mrd1 gene, responsible for multidrug-resistance, codes for P-glycoprotein. Biochem. Biophys. Res. Commun. 1986; 141: $956-62$

${ }^{21}$ Gottesman MM, Pastan I. Biochemistry of multidrug resistance mediated by the multidrug transporter. Ann. Rev. Biochem. 1993; 62: $385-427$

22 Iwu MM, Jackson JE, Schuster BG. Medicinal plants in the fight against leishmaniasis. Parasitology Today 1994; 10: 65-8

${ }^{23}$ Nielsen SF, Christensen SB, Cruciani G, Kharazmi A, Liljefors T. Antileishmanial chalcones: statistical design, synthesis, and threedimensional quantitative structure-activity relationship analysis. J. Med. Chem. 1998; 41: 4819-32

${ }^{24}$ Sittie AA, Lemmich E, Olsen CE, Hviid L, Kharazmi A, Nkrumah FK, et al. Structure-activity studies: in vitro antileishmanial and antimalarial activities of anthraquinones from Morinda lucida. Planta Medica 1999; 65: 259-61

${ }^{25}$ Akendengue B, Ngou-Milama E, Laurens A, Hocquemiller R. Recent advances in the fight against leishmaniasis with natural products. Parasite 1999; 6: 3-8

${ }^{26}$ Kayser O, Kiderlen AF, Folkens U, Kolodziej H. In vitro leishmanicidal activity of aurones. Planta Medica 1999; 65: 316-9

27 Strobl GR, von Kruedener S, Stöckigt J, Guengerich FP, Wolff T. Development of a pharmacophore for inhibition of human liver cytochrome P-450 2D6: molecular modeling and inhibition studies. J. Med. Chem. 1993; 36: 1136-45

\section{Prof. Jerzy W. Jaroszewski}

Department of Medicinal Chemistry The Royal Danish School of Pharmacy Universitetsparken 2

DK-2100 Copenhagen

Denmark

E-mail: jj@dfh.dk

Fax: +4535306040 